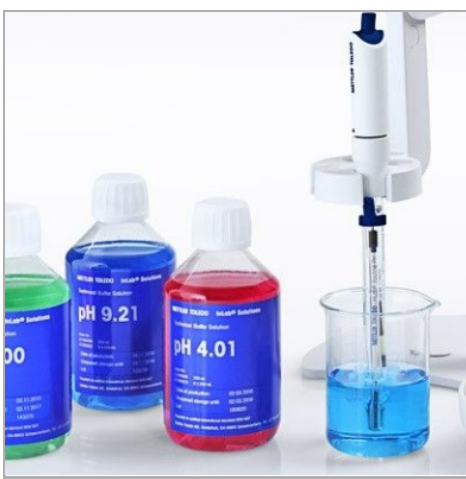

JUN 03, 2020

\section{open $\odot$ Access}

DOI:

dx.doi.org/10.17504/protocol s.io.bfybjpsn

Protocol Citation: Neilier Junior 2020. Glycine-HCl Buffer. protocols.io https://dx.doi.org/10.17504/p rotocols. io. bfybjpsn

License: This is an open access protocol distributed under the terms of the Creative Commons Attribution License, which permits unrestricted use, distribution, and reproduction in any medium, provided the original author and source are credited

Protocol status: Working We use this protocol and it's working

Created: May 05, 2020

Last Modified: Jun 03, 2020

PROTOCOL integer ID:

36579

Keywords: $\mathrm{pH}$, HendersonHasselback, Biochemistry, Molecular Biology

\section{(3) Glycine- $\mathrm{HCl}$ Buffer}

(7) 1 collection

Neilier Junior ${ }^{1}$

${ }^{1}$ Universidade Federal de Viçosa

Neilier Junior

Universidade Federal de Viçosa, University of Manitoba

\section{ABSTRACT}

A buffer solution has the function of resisting changes in $\mathrm{pH}$ even when adding powerful acids or bases. However, in the physiological environment the buffered system also provides cofactors for enzymatic reactions, critical salts and even essential nutrients for cells and tissues. Therefore, when trying to reproduce biological conditions in vitro, we must make the appropriate choice of the buffer. After all, it will provide the appropriate medium in which reactions will occur.

\section{MATERIALS \\ - Deionized Water \\ - pH Meter (sensitive) \\ - Glycine \\ - Hydrochloric Acid}

\section{SAFETY WARNINGS}

(4) Wear personal protective equipment: gloves, lab coat and mask.

\section{BEFORE START INSTRUCTIONS}

Organize your workspace.

Make sure all solutions and equipment are available.

\title{
Glycine-HCl Buffer
}


Note

pH range: (․ㅏ 2.2 to

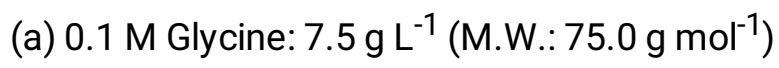

(b) $0.1 \mathrm{M}$ Hydrochloric acid

Mix \ $50 \mathrm{~mL}$ glycine and indicated volume of hydrochloric acid.

\begin{tabular}{|l|l|l|l|l|l|l|l|l|}
\hline $\mathrm{mL}$ of $\mathrm{HCl}$ & 44.0 & 32.4 & 24.2 & 16.8 & 11.4 & 8.2 & 6.4 & 3.6 \\
\hline $\mathrm{pH}$ & 2.2 & 2.4 & 2.6 & 2.8 & 3.0 & 3.2 & 3.4 & 3.6 \\
\hline
\end{tabular}

2 Mix and adjust the final volume to $\triangle 100 \mathrm{~mL}$ with deionized water.

3 Adjust the final $\mathrm{pH}$ using a sensitive $\mathrm{pH}$ meter 